\title{
Rabbit ovarian production of interleukin- 6 and its potential effects on gonadotropin-induced progesterone secretion in granulosa and theca cells
}

\author{
E Bréard, A Benhaïm, C Féral and $\mathbf{P}$ Leymarie \\ Laboratoire de Biochimie, EP 9 CNRS, IBBA Université de Caen, CHU Côte de Nacre, 14032 Caen Cedex, France \\ (Requests for offprints should be addressed to E Bréard)
}

\begin{abstract}
Recent studies suggest that non-steroid factors, such as cytokines, may play a role in ovarian processes. The purpose of this study was to explore cellular sites of interleukin (IL)-6 biosynthesis in rabbit follicles and to investigate IL-6 modulation in granulosa and theca cell functions. In this report development of rabbit preovulatory follicles was induced by $200 \mathrm{mIU}$ equine chorionic gonadotropin (eCG) daily for 2 days. Seventy-two hours after the last injection ovaries were excised and granulosa and theca cells isolated. The two types of cells were preincubated for $24 \mathrm{~h}$ in Minimum Essential Medium (MEM) with 5\% fetal calf serum (FCS), and then incubated for $24 \mathrm{~h}$ in MEM-2.5\% FCS with appropriate
\end{abstract}

stimulants. Results showed that rabbit granulosa and theca cell culture supernatants contained IL-6 bioactivity and that its production was inhibited by FSH and human CG and stimulated by IL-1. IL-6 inhibited gonadotropininduced progesterone production, but not basal secretion, in both cell types, without a cytotoxic effect. IL-6 affected cAMP generation and steps distal to cAMP formation, but the mechanism of IL-6 action on progesterone differed in granulosa and theca cells. Taken together our results suggest that gonadotropins, by inhibiting IL-6 production, could control, in our model, IL-6 modulation of gonadotropin action on steroidogenesis.

Journal of Endocrinology (1998) 159, 479-487

\section{Introduction}

In recent years, accumulating evidence has suggested that the immune system is an additional local regulator of ovarian functions, which are essentially modulated by the gonadotropins. Specifically, numerous studies have shown that a variety of cytokines modulate the reproductive process and are implicated as regulators of gonadal steroid secretion, corpus luteum function, embryo development and implantation.

Interleukin-6 (IL-6), a glycoprotein of $23-30 \mathrm{kDa}$, is one of these substances, initially identified as a T-cell derived cytokine which specifically promoted $\mathrm{T}$-cell activation, B-cell differentiation and antibody production. It is synthesized by a large variety of cell types including fibroblasts, mast cells, endothelial cells, monocytes/ macrophages, anterior pituitary cells and keratinocytes (Spangelo et al. 1990a,b, Van Snick 1990). The regulation of IL- 6 production has been an area of intense investigation and IL-1, tumor necrosis factor- $\alpha$ (TNF $\alpha$ ), diacylglycerols, calcium ionophore and serum all have been reported to stimulate IL-6 production in vitro (Kishimoto 1989).

Evidence of IL-6 release by the ovary was demonstrated by Watson et al. (1990), who showed that basal production of IL-6 occurs in cultures of primary ovarian tumors and ovarian cancer cell lines. Then it was demonstrated that granulosa cells of many species are an active site of IL-6 biosynthesis (Gorospe et al. 1992, Fong et al. 1994, Machelon et al. 1994a,b). But, although involvement of IL-6 in granulosa steroidogenesis regulation is well documented (Gorospe et al. 1992, Alpizar \& Spicer 1993, Gorospe \& Spangelo 1993, Pitzel et al. 1993, Hughes et al. 1994, Machelon et al. 1994b, 1995), no studies of its effects on theca steroidogenesis have been reported.

The aim of the present study was to investigate in vitro IL-6 production by hyperstimulated rabbit ovary, from which both cell types can be efficiently obtained, and to assess in vitro IL-6 regulatory effects on cell number and progesterone production.

\section{Materials and Methods}

\section{Reagents}

Minimum Essential Medium (MEM) with Earle's salts, RPMI 1640, and fetal calf serum (FCS) were obtained from Eurobio (Les Ulis, France). Purified ovine folliclestimulating hormone (FSH) (USDA-o-FSH 18, 1640 IU/ $\mathrm{mg}$ ) was provided by the National Hormone and Pituitary 
Program (National Institute of Diabetes, Digestive and Kidney Diseases, Bethesda, MD, USA).

Forskolin, cholera toxin, collagenase type II, protease type XIV, hyaluronidase type II, $\mathrm{N}_{6} \mathrm{O}_{2}$ (butyryl) 2 cyclic AMP (Db-cAMP), 2,3-bis(2-methoxy-4-nitro-5-sulfophenyl)-2H-tetrazolium-5-carboxanilide (XTT), phenazine methosulfate, BSA, trichloroacetic acid and EGTA were obtained from Sigma-Chimie (L'Isle d'Abeau, France). Human recombinant interleukin-6 (100 IU/ng) and human recombinant interleukin-1 $\beta$ (50 IU/ng) were purchased from Boehringer-Mannheim (Meylan, France). A commercial preparation of human chorionic gonadotropin (hCG) (Pregnyl; 3500-4000 IU/mg) was supplied by Organon (Serifontaine, France); equine gonadotropin (eCG) (Chrono-gest) was obtained from Intervet (Angers, France). Embutramide T61 was obtained from Distrivet (Paris, France).

Progesterone antibody was supplied by the Fondation de Recherche en Hormonologie, France. $\left[{ }^{3} \mathrm{H}\right]$ Progesterone $(80-110 \mathrm{Ci} / \mathrm{mmol})$ and a cAMP RIA kit were obtained from Amersham (Les Ulis, France).

\section{Animals}

For this study, we used HY white female rabbits, 1215 weeks old.

The development of preovulatory follicles was induced in immature rabbits by intramuscular injection of $200 \mathrm{IU}$ eCG daily for 2 days. The rabbits were killed by intracardiac injection of $2 \mathrm{ml}$ narcotic (embutramide T61), $72 \mathrm{~h}$ after the last injection of eCG. The ovaries were excised and placed in culture medium. For each experiment, 80-100 follicles $(0 \cdot 8-1 \cdot 5 \mathrm{~mm}$ diameter $)$ were dissected out and cleared of interstitial tissue stereomicroscopically.

\section{Cell preparation}

Dispersed granulosa and theca cells were obtained as described previously (Féral et al. 1990). Briefly, follicles were cut in half in MEM- $0 \cdot 1 \%$ BSA containing $20 \mathrm{mM}$ Hepes, $50 \mathrm{IU} / \mathrm{ml}$ penicillin, $50 \mu \mathrm{g} / \mathrm{ml}$ streptomycin, $0 \cdot 1 \%$ BSA, and $6.8 \mathrm{mM}$ EGTA for $15 \mathrm{~min}$. The released granulosa cells and the follicles were then centrifuged together for $10 \mathrm{~min}$ at $150 \mathrm{~g}$ and resuspended in MEMBSA containing $0.5 \mathrm{M}$ sucrose and $1.8 \mathrm{mM}$ EGTA for $5 \mathrm{~min}$ before being centrifuged again for $10 \mathrm{~min}$ at $150 \mathrm{~g}$. Granulosa cells were then gently scraped away from the theca with a microspatula under a dissecting microscope. The dispersed granulosa cells were then pelleted by centrifugation at $150 \mathrm{~g}$, subjected to mechanical dissociation, washed twice in MEM- $0 \cdot 1 \%$ BSA, and suspended in MEM supplemented with 5\% FCS.

In order to eliminate the few granulosa cells remaining on the theca, the pieces of tissue were placed in MEM containing $0 \cdot 1 \%$ collagenase and $0 \cdot 1 \%$ hyaluronidase (type II) for $10 \mathrm{~min}$ at $37^{\circ} \mathrm{C}$. After a short centrifugation $(600 \mathrm{~g}, 30 \mathrm{~s})$ of thecal tissue, thecal cells were gently dissociated by incubation for $10 \mathrm{~min}$ at $37^{\circ} \mathrm{C}$ in MEM containing $0 \cdot 2 \%$ hyaluronidase and $0.1 \%$ protease (type XIV). They were then washed three times in MEM-0.1\% BSA, and suspended in MEM-5\% FCS.

\section{Granulosa and theca cells culture}

Cells were cultured in Costar 48-well tissue culture plates. Cell concentrations were $10^{5}$ cells/well for the study of progesterone production or cell number determination and $2.5 \times 10^{5}$ cells/well for the measurement of IL-6 activity. Granulosa and theca cells were preincubated for $24 \mathrm{~h}$ at $37{ }^{\circ} \mathrm{C}$ in a total volume of $0.5 \mathrm{ml}$ MEM-5\% FCS, under an atmosphere of $5 \% \mathrm{CO}_{2}$ and $95 \%$ air. Supernatants were then removed and cells were incubated at $37^{\circ} \mathrm{C}$ in MEM-2.5\% FCS containing the appropriate stimulants, with or without IL-6, for a further $24 \mathrm{~h}$. Then cell-free supernatants were collected and frozen until progesterone and IL-6 bioactivity measurement. Cell layers were used to determine cell number. The viability of the suspensions of both cell types at seeding was higher than $90 \%$, and we found no statistical difference in granulosa and theca cells numbers at seeding or after culture without hormones or substances.

\section{Cell number determination}

Granulosa and theca cell numbers from each culture well were estimated by measuring DNA content using the fluorometric technique described by Labarca \& Paigen (1980) and also by a colorimetric estimation of mitochondrial activity evaluated by conversion of the tetrazolium salt XTT into its formazan product, according to Mosmann (1983). This colorimetric assay allows quantification of living metabolically active cells. This assay has previously been used in granulosa cells by Best et al. (1994). Briefly, at the end of the $24 \mathrm{~h}$ culture period, supernatants were removed and granulosa or theca cells were incubated in $200 \mu \mathrm{l}$ serum-free MEM with XTT $(0.25 \mathrm{mg} / \mathrm{ml})$ and phenazine methosulfate $(1.9 \mu \mathrm{g} / \mathrm{ml})$ for $3 \mathrm{~h}$. The production of formazan by the cells was quantified by measuring absorbance at $570 \mathrm{~nm}$ with a multiwell ELISA reader.

\section{IL-6 assay}

IL-6 activity was determined by the capacity of granulosa and theca cell supernatant to enhance 7TD1 hybridoma cell proliferation (Gorospe \& Spangelo 1993). Briefly, 2500 cells/well were placed in RPMI 1640-10\% FCS, containing $50 \mu \mathrm{M} \quad \beta$-mercaptoethanol and antibiotics. These cells were cultured for $72 \mathrm{~h}$ in the presence of $50 \mu \mathrm{l}$ RPMI containing increasing concentration of IL-6 $(1-1000 \mathrm{pg} / \mathrm{ml})$ or $50 \mu \mathrm{l}$ granulosa or theca cell culture 
supernatant. RPMI $(50 \mu \mathrm{l})$ containing XTT $(0 \cdot 25 \mathrm{mg} / \mathrm{ml})$ and phenazine methosulfate $(1.9 \mu \mathrm{g} / \mathrm{ml})$ was then added for a final $4 \mathrm{~h}$ incubation. Cell number was then estimated by measuring absorbance at $570 \mathrm{~nm}$ with a multiwell micro-ELISA reader. 7TD1 hybridoma cells are very sensitive and specific for IL-6, and they fail to grow in response to any other cytokines or hormones tested (Spangelo et al. 1990a).

\section{Progesterone production}

Progesterone levels were directly measured in granulosa or theca cell media by RIA using the specific progesterone antibody (Benhaïm et al. 1987). The sensitivity of the assay was $6 \mathrm{pg} /$ tube. The intra- and interassay coefficients of variation were 5 and $9 \%$ respectively. The cross reactivity with $17 \alpha$-hydroxyprogesterone was $0 \cdot 01 \%$.

\section{Statistics}

Data are the mean \pm S.E.M. of at least three experiments performed in triplicate. One rabbit was used for each experiment. Results for progesterone secretion and cell number determination were expressed as the percentage change from control. The control results were obtained with cells cultured in MEM-2.5\% FCS, without added substances, and run in parallel with test wells. Statistical differences between treatment groups were assessed by two-way ANOVA, followed by Fisher's test and considered significant at $P<0 \cdot 05$. Data in Tables 1 and 2 were assessed by Student's $t$-test analysis.

\section{Results}

Biological activity was regulated by gonadotropins and IL-1 $\beta$ in granulosa and theca cells

As shown in Fig. 1, IL-6 bioactivity was detected in rabbit granulosa and theca cell culture medium. Medium supplemented with 10\% FCS did not contain measurable amounts of IL-6 (data not shown).

In the absence of gonadotropins, IL-6 bioactivity was similar in media from granulosa and theca cells $(11.5$ and $11.7 \mathrm{pg} / 2 \cdot 5 \times 10^{5}$ cells respectively). IL-6 production was inhibited in a dose-dependent manner, for both types of cells, by high doses of gonadotropins (Fig. 1).

When IL-1 $\beta$ was added to granulosa and theca cell cultures, IL-6 production was significantly enhanced and this enhancement was statistically significant in granulosa cells (Fig. 2). In the presence of both IL-1 $\beta$ and gonadotropins we no longer observed the inhibitory effect of gonadotropins on granulosa and theca IL-6 production.

\section{Estimation of granulosa and theca cell number}

We estimated the amount of DNA per well after cell culture and the results demonstrated that the higher dose


Figure 1 Dose-dependent effect of gonadotropins on IL-6 secretion by granulosa cells (A) or theca cells (B). Results are the mean \pm S.E.M. of $n$ experiments performed in triplicate $(A, n=6$; $\mathrm{B}, n=4) .{ }^{*} P<0 \cdot 05 ;{ }^{*} P<0 \cdot 01$ compared with the absence of gonadotropins.

of IL-6 (25 ng/ml), in the presence or absence of low doses of gonadotropins $(1 \mathrm{ng} / \mathrm{ml}$ for $\mathrm{FSH}$ and $10 \mathrm{mIU} / \mathrm{ml}$ for hCG), did not affect significantly the amount of DNA (data not shown). By using a more sensitive assay, the colorimetric method of Mosmann (1983), a slight dosedependent enhancement of the number of the two types of cells was obtained when increasing concentrations of IL-6 $(1-25 \mathrm{ng} / \mathrm{ml})$ were added to the culture medium in 

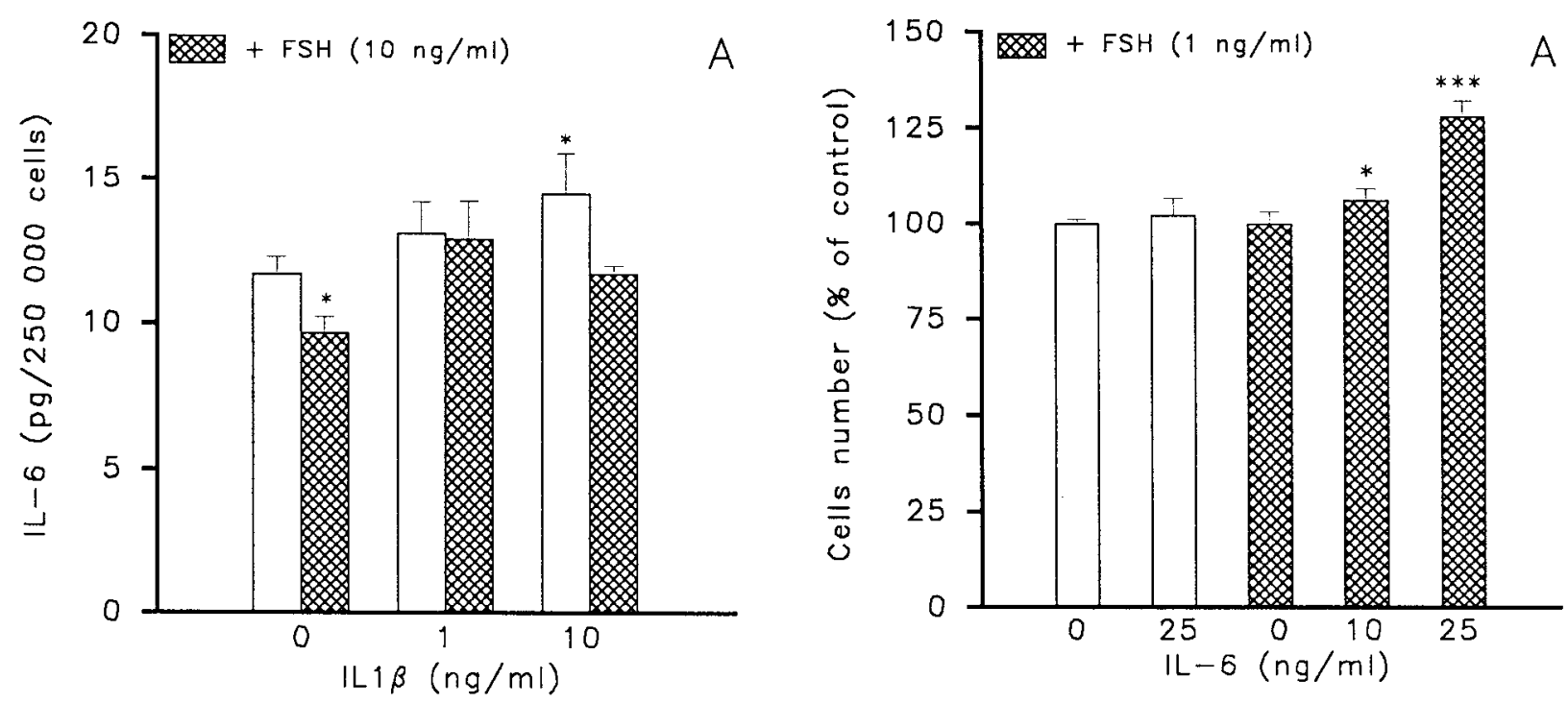

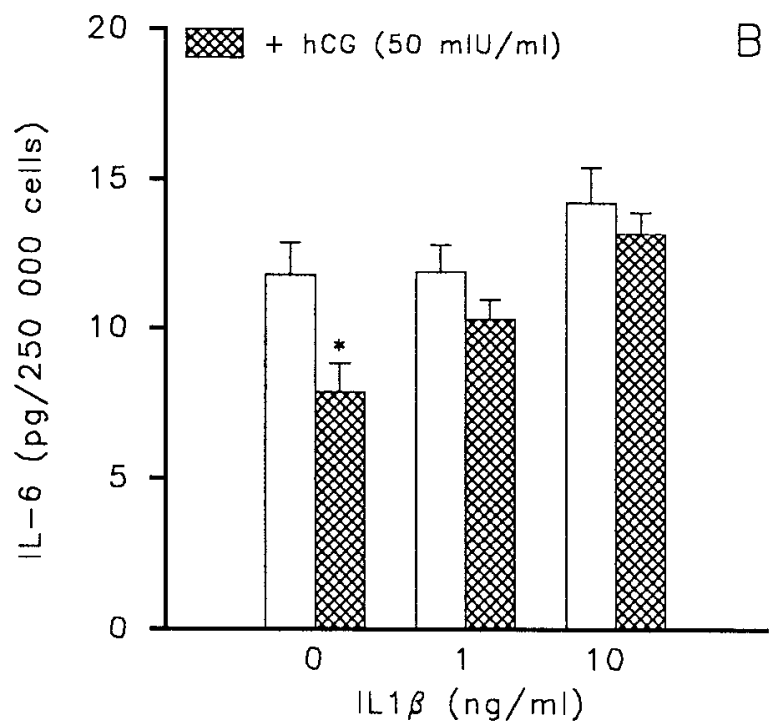

Figure 2 Dose-dependent effect of IL-1, in the presence or absence of gonadotropins, on IL- 6 secreted by granulosa cells (A) or theca cells (B). Results are the mean \pm S.E.M. of $n$ experiments performed in triplicate $(A, n=6 ; B, n=4) .{ }^{*} P<0.05$ compared with control, without IL-1 and gonadotropins.

addition to FSH or hCG (Fig. 3). However, no significant effect was observed with IL-6 alone or gonadotropins alone (Fig. 3).

Effect of IL-6 on gonadotropin-induced progesterone secretion in cultured granulosa and theca cells

As shown in Fig. 4A, basal progesterone secreted by granulosa cells $\left(510 \pm 11 \mathrm{pg} / 10^{5}\right.$ cells $)$ was not modified

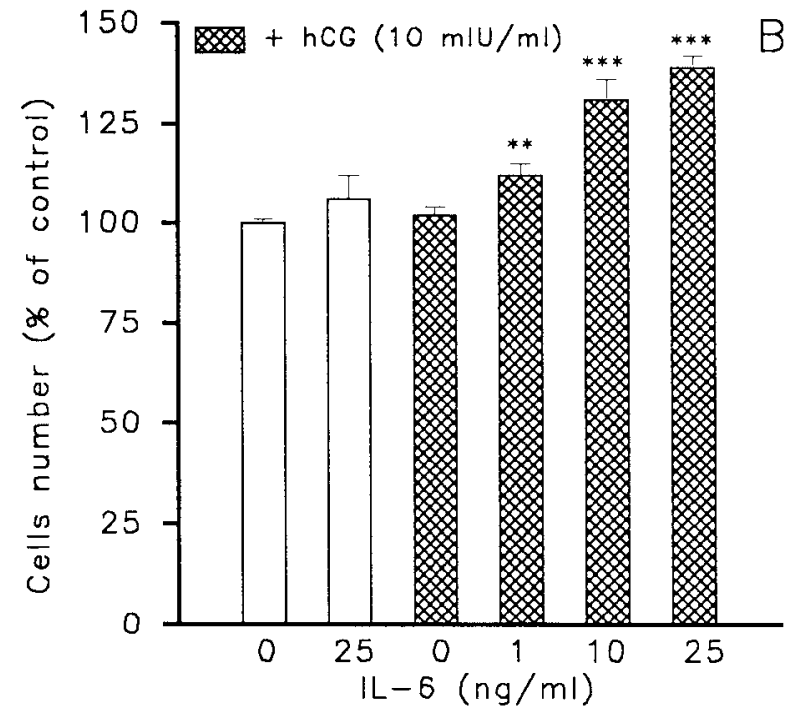

Figure 3 Effect of increasing concentrations of IL- 6 on the number of granulosa cells cultured in the presence of $\mathrm{FSH}$ $(1 \mathrm{ng} / \mathrm{ml})(\mathrm{A})$, or of theca cells cultured in the presence of hCG $(10 \mathrm{mlU} / \mathrm{ml})(B)$. Results are the mean \pm S.E.M. of $n$ experiments performed in triplicate $(\mathrm{A}, n=3 ; \mathrm{B}, n=4) .{ }^{*} P<0 \cdot 05 ;{ }^{*} P<0 \cdot 01$; ${ }^{* * *} P<0.001$ compared with control, without gonadotropins.

by the presence of various doses of IL-6. FSH $(1 \mathrm{ng} / \mathrm{ml})$ induced a 15 -fold increase in progesterone production. Increasing concentrations of IL-6 $(1-50 \mathrm{ng} / \mathrm{ml})$ inhibited FSH-stimulated progesterone secretion in granulosa cells in a dose-dependent manner $(P<0 \cdot 001)$. The response to higher doses of FSH (5 or $10 \mathrm{ng} / \mathrm{ml}$ ), which could induce an increase of progesterone secretion as high as 25 times the basal level, was not changed by IL-6 (data not shown). 

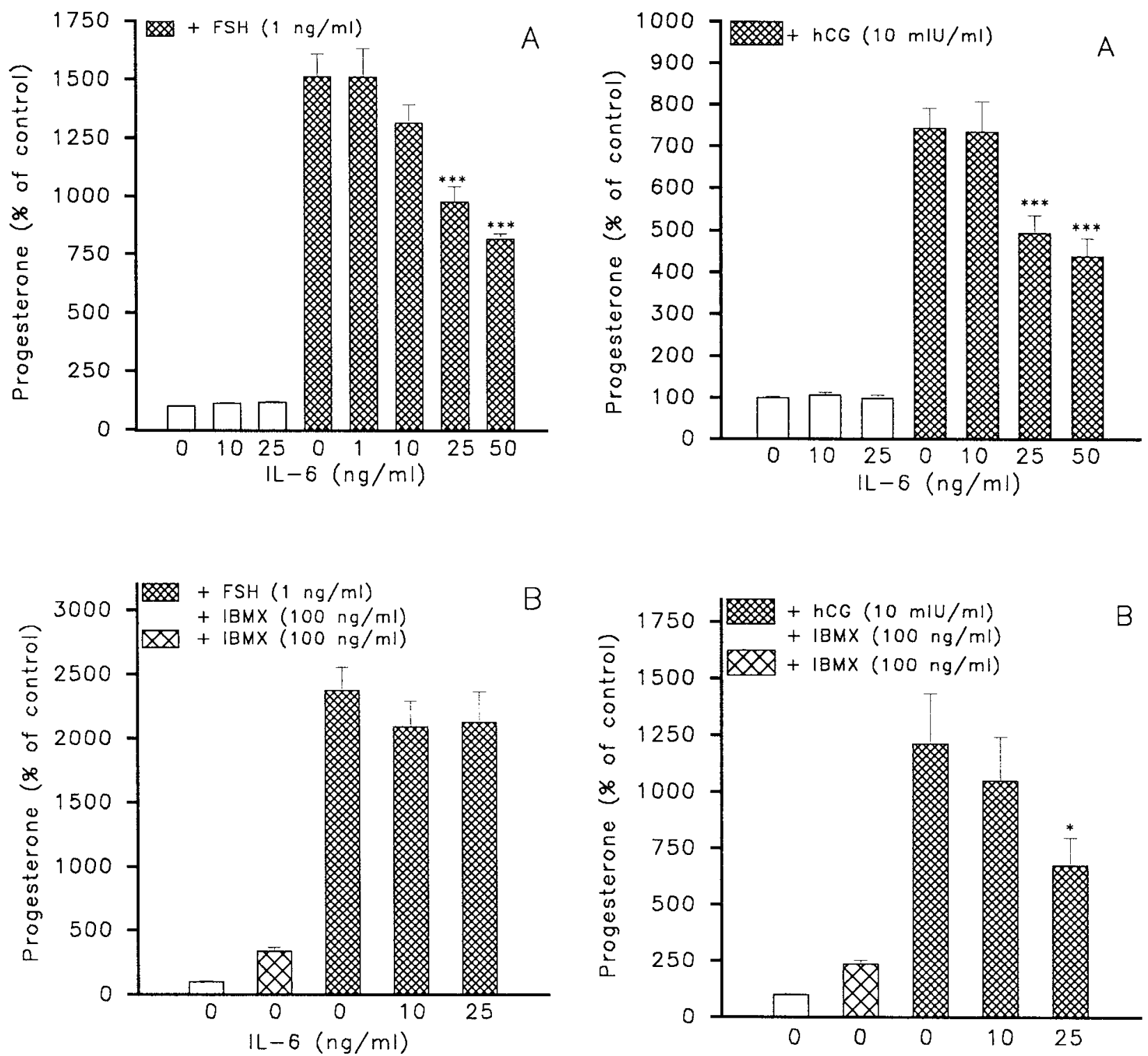

Figure 4 Effect of increasing doses of IL-6 on progesterone secretion in granulosa cells under basal or FSH $(1 \mathrm{ng} / \mathrm{ml})$ stimulated conditions in the absence (A) or presence (B) of IBMX $(100 \mathrm{ng} / \mathrm{ml})$. Results are the mean \pm S.E.M. of $n$ experiments performed in triplicate. Values are expressed as percentage of mean value of progesterone secreted by untreated cells. ${ }^{* * *} P<0.001$ compared with FSH alone. (A, $n=5$, control: $510 \pm 11 \mathrm{pg} / 10^{5}$ cells; B, $n=3$, control: $682 \pm 35 \mathrm{pg} / 10^{5}$ cells.)

In the presence of 3-isobutyl-1-methylxanthine (IBMX), an inhibitor of phosphodiesterase activity, the inhibitory effect of IL-6 $(25 \mathrm{ng} / \mathrm{ml})$ on FSH-stimulated progesterone secretion was no longer seen (Fig. 4B).

Basal progesterone production in theca cells $(334 \pm$ $14 \mathrm{pg} / 10^{5}$ cells) was not significantly modified in the presence of IL-6 (Fig. 5A). Treatment of theca cells with

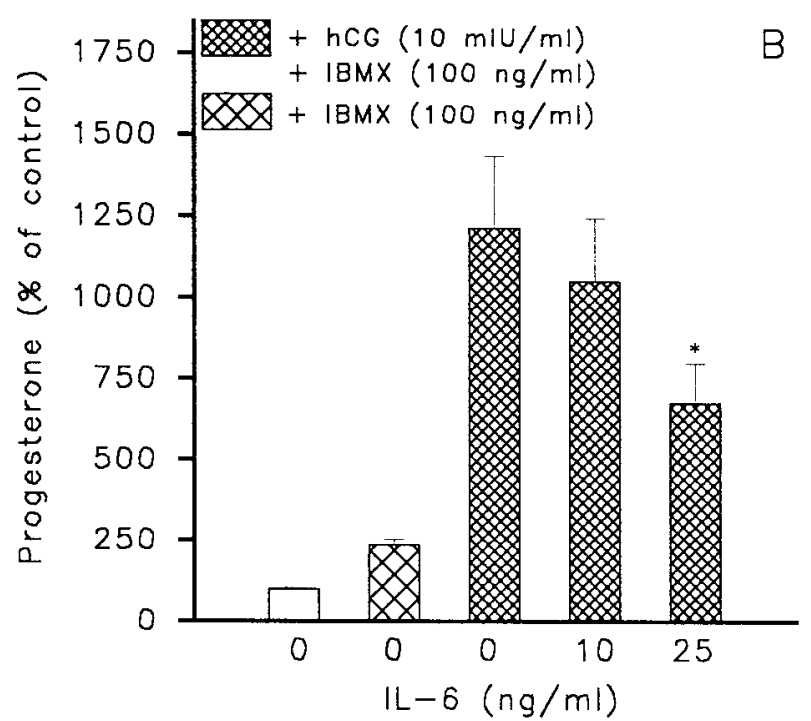

Figure 5 Effect of increasing doses of IL-6 on progesterone secretion in theca cells under basal or hCG $(10 \mathrm{mlU} / \mathrm{ml})$ stimulated conditions in the absence (A) or presence (B) of IBMX $(100 \mathrm{ng} / \mathrm{ml})$. Results are the mean \pm S.E.M. of three experiments performed in triplicate. Values are expressed as percentage of mean value of progesterone secreted by untreated cells. ${ }^{* * *} P<0 \cdot 001$ compared with hCG alone (A) and $* P<0 \cdot 05$ compared with hCG+IBMX (B). (A, control: $334 \pm 14 \mathrm{pg} / 10^{5}$ cells; $\mathrm{B}$, control: $390 \pm 15 \mathrm{pg} / 10^{5}$ cells.)

$10 \mathrm{mIU} / \mathrm{ml}$ hCG resulted in a 7·4-fold increase in progesterone secretion. Concomitant treatment with increasing doses of IL-6 caused a dose-dependent inhibition of hCG-stimulated progesterone production. Addition of IBMX $(100 \mathrm{ng} / \mathrm{ml})$ did not modify the inhibitory effect of $25 \mathrm{ng} / \mathrm{ml} \mathrm{IL-6} \mathrm{(Fig.} \mathrm{5B).}$ 
Table 1 Effect of IL- 6 on progesterone production by granulosa cells induced by Db-cAMP $(0 \cdot 1 \mathrm{mM})$ or forskolin $(0 \cdot 25 \mu \mathrm{g} / \mathrm{ml})$. Results are the mean \pm S.E.M. of triplicate well cultures. Values are $\mathrm{pg} / 10^{5}$ cells

\begin{tabular}{|c|c|c|c|c|c|}
\hline & Experiment & Control & Agent alone & $10 \mathrm{ng} / \mathrm{ml}$ & $25 \mathrm{ng} / \mathrm{ml}$ \\
\hline \multirow[t]{3}{*}{ Db-cAMP } & 1 & $474 \pm 46$ & $\overline{5016 \pm 265}$ & $5625 \pm 227^{\mathrm{NS}}$ & $5700 \pm 147^{a}$ \\
\hline & 2 & $713 \pm 69$ & $2995 \pm 50$ & $3370 \pm 107^{\mathrm{a}}$ & $3420 \pm 93^{b}$ \\
\hline & 3 & $335 \pm 17$ & $3907 \pm 228$ & $4757 \pm 285^{a}$ & $5545 \pm 415^{b}$ \\
\hline \multirow[t]{2}{*}{ Forskolin } & 4 & $445 \pm 24$ & $1690 \pm 80$ & $2543 \pm 182^{b}$ & $2970 \pm 205^{c}$ \\
\hline & 5 & $636 \pm 16$ & $5037 \pm 165$ & $5046 \pm 496^{\mathrm{NS}}$ & $6963 \pm 165^{c}$ \\
\hline
\end{tabular}

${ }^{\mathrm{a}} \mathrm{P}<0.05 ;{ }^{b} \mathrm{P}<0.01 ;{ }^{\mathrm{c}} \mathrm{P}<0.001$ versus Db-cAMP or forskolin alone; NS: not significant.

Effect of IL-6 on granulosa and theca cells treated with $D b-c A M P$ and adenylate cyclase-stimulating agents

In order to determine if the IL-6 inhibition of gonadotropin-induced progesterone production occurred downstream or upstream of the adenylate cyclase activation, granulosa and theca cells were cultured in the presence of Db-cAMP or adenylate cyclase-stimulating agents.

In the presence of $0.1 \mathrm{mM}$ Db-cAMP, stimulated progesterone production was slightly enhanced by IL-6 in the three experiments performed (Table 1). A more important IL-6 stimulatory effect was observed when granulosa cells were cultured in the presence of forskolin $(0 \cdot 25 \mu \mathrm{g} / \mathrm{ml})$, an agent that stimulates adenylate cyclase (Table 1). However, in the presence of cholera toxin, progesterone secretion by granulosa cells was not modified by addition of 10 or $25 \mathrm{ng} / \mathrm{ml}$ of IL-6 (Fig. 6).

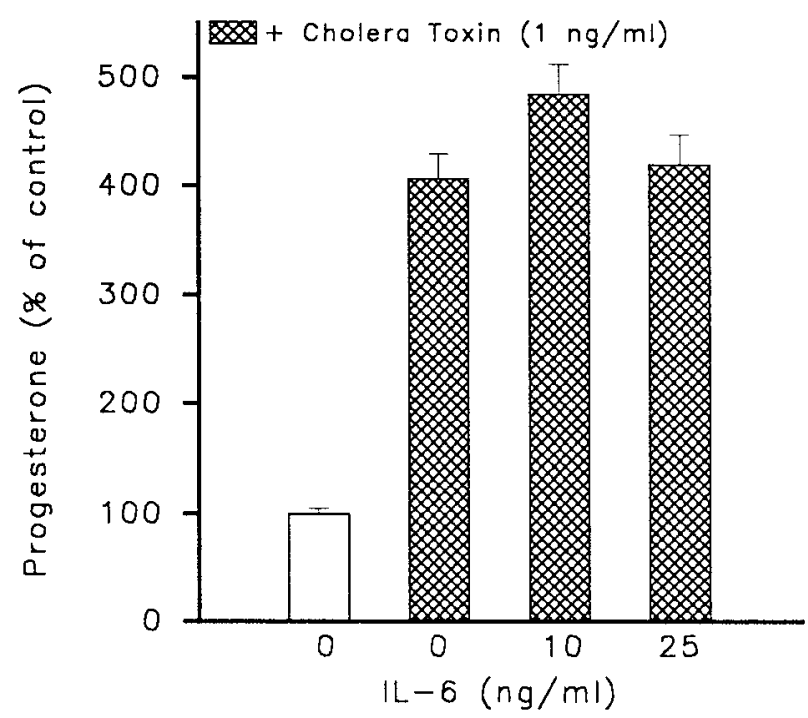

Figure 6 Effect of IL-6 on progesterone secretion by granulosa cells induced by cholera toxin $(1 \mathrm{ng} / \mathrm{ml})$. Results are the mean \pm S.E.M. of three experiments performed in triplicate. Values are expressed as percentage of mean value of progesterone secreted by untreated cells. (Control: $541 \pm 29 \mathrm{pg} / 10^{5}$ cells.)
In theca cells, the inhibitory effect of IL-6 on progesterone production induced by hCG appeared to result from a mechanism different from the one observed for granulosa cells. Indeed, IL-6 inhibited significantly, in a dose-dependent manner, progesterone production induced by Db-cAMP $(1 \mathrm{mM})$ or forskolin $(1 \mu \mathrm{g} / \mathrm{ml})$ (Table 2). However, when steroidogenesis was enhanced by cholera toxin, IL-6 was without effect on progesterone production (Fig. 7).

\section{Discussion}

All of our results indicate that IL-6 may act as a paracrine or autocrine regulator of ovarian steroidogenesis. Indeed granulosa cells and, as we have observed for the first time, theca cells produced measurable amounts of IL-6 and this cytokine had the ability to inhibit in vitro differentiation processes induced by gonadotropins.

The capacity to produce IL-6 is common also to cell types other than granulosa and theca cells such as lymphocytes or macrophages. But lymphocytes do not adhere to culture dishes and thus are likely to have been removed by the end of the $24 \mathrm{~h}$ preincubation, and macrophages are known to undergo apoptosis within $24 \mathrm{~h}$ when placed in culture in the absence of added cytokines, such as IL-1 $\beta$, $\mathrm{TNF} \alpha$, granulocyte-macrophage colony stimulating factor or interferon- $\gamma$ (Mangan \& Wahl 1991). Moreover, Machelon et al. (1994a) working on human granulosa cells demonstrated that levels of IL-6 transcripts were similar in preparations treated to remove immune cells and in untreated ones, and concluded that IL-6 biosynthesis by macrophages was a negligible source of IL-6. Taken together, these observations seem to exclude the possibility that cytokine bioactivity detected in supernatants of cell cultures in our study could originate from white blood cells (Bréard et al. 1998).

Our observation that production of IL-6 could be inhibited by gonadotropins both in granulosa and theca cells contrasts with previous observations in the rat. In that species, immunoreactive IL-6 was detected in the supernatant of granulosa cell cultures (Gorospe et al. 1992, 
Table 2 Effect of IL- 6 on progesterone production by theca cells induced by Db-cAMP $(1 \mathrm{mM})$ or forskolin $(1 \mu \mathrm{g} / \mathrm{ml})$. Results are the mean \pm S.E.M. of triplicate well cultures. Values are $\mathrm{pg} / 10^{5}$ cells

\begin{tabular}{|c|c|c|c|c|c|c|}
\hline \multirow{2}{*}{\multicolumn{2}{|c|}{ Experiment }} & \multirow[b]{2}{*}{ Control } & \multirow[b]{2}{*}{ Agent alone } & \multirow[b]{2}{*}{$10 \mathrm{ng} / \mathrm{ml}$} & \multirow[b]{2}{*}{$25 \mathrm{ng} / \mathrm{ml}$} & \multirow[b]{2}{*}{$50 \mathrm{ng} / \mathrm{ml}$} \\
\hline & & & & & & \\
\hline \multirow[t]{3}{*}{ Db-cAMP } & 1 & $297 \pm 17$ & $4914 \pm 241$ & $3941 \pm 169^{b}$ & $2317 \pm 107^{c}$ & $1497 \pm 45^{c}$ \\
\hline & 2 & $467 \pm 15$ & $4146 \pm 159$ & $3243 \pm 196^{b}$ & $2826 \pm 252^{\mathrm{c}}$ & $2576 \pm 93^{c}$ \\
\hline & 3 & $275 \pm 8$ & $3214 \pm 129$ & $3055 \pm 261^{\mathrm{NS}}$ & $2926 \pm 159^{\text {NS }}$ & $740 \pm 102^{\circ}$ \\
\hline \multirow[t]{2}{*}{ Forskolin } & 4 & $297 \pm 17$ & $4651 \pm 122$ & $3309 \pm 80^{c}$ & $1879 \pm 53^{\mathrm{c}}$ & $1418 \pm 65^{c}$ \\
\hline & 5 & $509 \pm 13$ & $3584 \pm 208$ & $3327 \pm 137^{\mathrm{NS}}$ & $2857 \pm 92^{b}$ & $2021 \pm 112^{c}$ \\
\hline
\end{tabular}

${ }^{\mathrm{b}} \mathrm{P}<0 \cdot 01 ;{ }^{\mathrm{c}} \mathrm{P}<0 \cdot 001$ versus Db-cAMP or forskolin alone; NS: not significant.

Gorospe \& Spangelo 1993) and various doses of FSH were found to be able to induce a significant increase in IL-6 production. Results from this study also suggested that cAMP could be the second messenger of the gonadotropin action (Gorospe \& Spangelo 1993). However, in other studies, FSH or hCG were not found to modify significantly the release of IL-6 by human or primate granulosa cells (Machelon et al. 1994a, 1995), and more recently it was observed that IL-6 production by primate granulosa cells was not detected in the presence of Db-cAMP (Machelon et al. 1995). Hence it appears that regulation by gonadotropins of IL-6 release in ovarian cells could be species dependent.

The regulatory effect of gonadotropin observed in our study could result from an indirect mechanism. We previously observed that estradiol was released in response to FSH and hCG by cultured granulosa and theca cells respectively (Féral et al. 1995) and estradiol has been

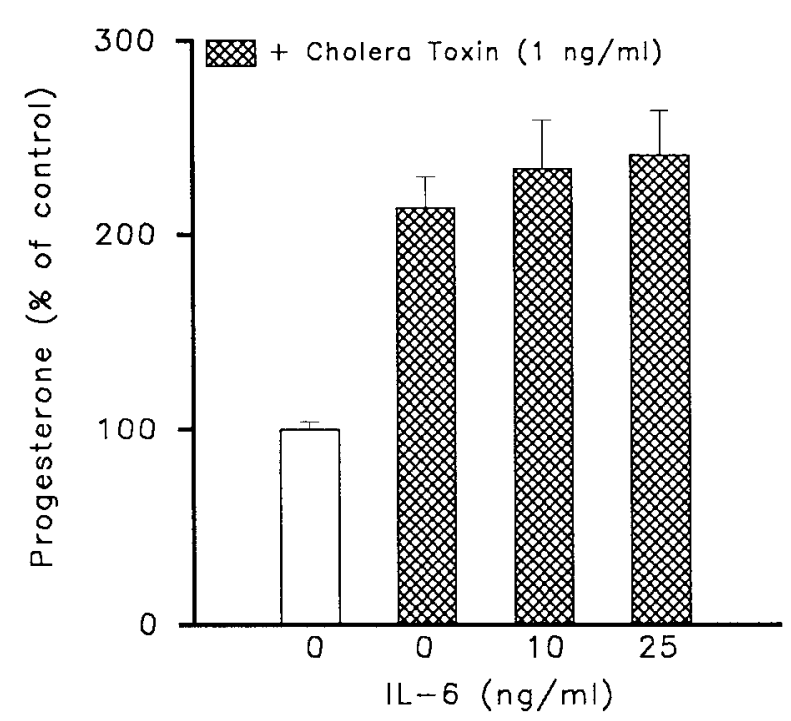

Figure 7 Effect of IL-6 on progesterone secretion by theca cells stimulated by cholera toxin. Results are the mean \pm S.E.M. of three experiments performed in triplicate. Values are expressed as percentage of mean value of progesterone secreted by untreated cells. (Control: $526 \pm 17 \mathrm{pg} / 10^{5}$ cells.) shown to inhibit the ovarian IL-6 expression (Pottratz et al. 1994). Moreover, IL-1 stimulated IL-6 production and we previously reported that, in the rabbit, IL-1 bioactivity production in cultured granulosa and theca cell supernatants was inhibited by gonadotropins (Bréard et al. 1998). So we can assume that gonadotropins could inhibit IL-6 release at least in part through both an increase in estradiol production and a decrease in IL-1 production.

Concerning the action of IL-6 on rabbit steroidogenesis, IL-6 had no effect on basal progesterone production by granulosa and theca cells cultured for $24 \mathrm{~h}$ as observed in monkey granulosa and porcine luteal cells (Pitzel et al. 1993, Machelon et al. 1995). When progesterone production was stimulated in vitro by physiological doses of gonadotropins, we observed an inhibition of its production by IL-6 in both types of follicular cells and this inhibition was not the result of an IL-6 cytotoxic effect. In fact, the ability of IL-6 to inhibit differentiation seems in keeping with its ability to promote an increase in cell number.

Our observation that IL-6 acted in an inhibitory way on steroidogenesis induced by gonadotropins in rabbit granulosa cells is in agreement with studies in several other species (rat (Gorospe et al. 1992, Gorospe \& Spangelo 1993, Hughes et al. 1994), bovine (Alpizar \& Spicer 1993)). However, in porcine and monkey granulosa cells (Pitzel et al. 1993, Machelon et al. 1995), no effect of IL-6 on hCG-stimulated progesterone secretion was observed, and Machelon et al. (1994a) recently reported that in human granulosa cells, IL-6 stimulated progesterone production induced by hCG.

When studying the action of IL-6 on steroidogenesis in rabbit granulosa cells, we unexpectedly observed that IL-6, while reducing progesterone production induced by FSH, increased at the same time progesterone synthesis induced by $\mathrm{Db}-\mathrm{cAMP}$ or forskolin. This observation suggested that IL-6 could induce a post-cAMP step stimulatory effect associated with a pre-cAMP step inhibitory effect. This latter effect was apparently predominant when an intracellular cAMP rise was induced by $\mathrm{FSH}$, since only the inhibitory effect was observed. Such antagonistic pre- and post-cAMP effects were previously observed when studying the role of IL-1 in the rabbit (Bréard et al. 1998) as well as in other species (Gottschall 
et al. 1988, Santana et al. 1996). However, in the present study, we could not document an inhibition by IL-6 of the FSH-induced cAMP accumulation (unpublished data), because, as previously reported (Bréard et al. 1998), the dose of FSH used was unable to stimulate granulosa cAMP accumulation, although this gonadotropin concentration stimulated 15-fold the basal progesterone production (an apparent discrepancy which has been largely reported in the past (Azhar \& Menon 1979)). However, the precAMP defect could be localized by the use of cholera toxin. In the presence of this substance, we observed neither the IL-6 inhibitory effect on granulosa progesterone production nor the stimulatory IL-6 effect which occurred at a post-cAMP step. This result demonstrates that the IL-6 inhibitory effect on a pre-cAMP step was decreased when adenylate cyclase was stimulated by cholera toxin, suggesting that IL-6 prevented in part the activation of adenylate cyclase by a $G$ protein. In the same way, in the presence of IBMX, FSH-induced progesterone production was no longer inhibited by IL-6. This result suggests that the increase in the CAMP pool induced by IBMX could induce a post-cAMP effect overcoming the pre-cAMP inhibitory effect.

In theca cells, we observed a constant inhibitory effect of IL- 6 on progesterone production stimulated by hCG, forskolin or Db-cAMP. These results indicate that, in contrast to its effect on granulosa cells, IL-6 exerted on theca cells an inhibitory effect at a post-cAMP step. We found no explanation for the fact that in the presence of cholera toxin IL-6 did not affect progesterone production in theca cells.

In summary, it appears from our results that IL-6 might be a factor inducing granulosa and theca cell dedifferentiation, reflected here by a decrease in progesterone synthesis. Surprisingly the post-cAMP mechanism of this modulation by IL-6 of steroidogenesis induced by gonadotropins did not seem to be identical in granulosa and theca cells. However, gonadotropins were apparently able to control the negative modulation of this cytokine on their steroidogenic action by inhibiting its production.

\section{References}

Alpizar E \& Spicer LJ 1993 Effects of interleukin-6 on proliferation and follicle-stimulating hormone-induced estradiol production by bovine granulosa cells in vitro: dependence on size of follicle. Biology of Reproduction 49 38-43.

Azhar S \& Menon KMJ 1979 Receptor mediated gonadotrophin action in the ovary. Regulatory role of cyclic nucleotide phosphodiesterase(s) in the intracellular cAMP turnover and gonadotrophin stimulated progesterone production by rat ovarian cells. Biochemistry Journal 180 201-211.

Benhaïm A, Bonnamy PJ, Papadopoulos V, Mittre H \& Leymarie P 1987 In vitro action of PGF2 $\alpha$ on progesterone and cAMP synthesis in small bovine luteal cells. Prostaglandins 33 227-239.

Best CL, Pudney J, Anderson DJ \& Hill JA 1994 Modulation of human granulosa cell steroid production in vitro by tumor necrosis factor alpha: implications of white blood cells in culture. Obstetrics and Gynecology 84 121-127.
Bréard E, Delarue B, Benhaïm A, Féral C \& Leymarie P 1998 Inhibition by gonadotrophins of interleukin-1 production by rabbit granulosa and theca cells. Effects on gonadotropin induced progesterone production. European Journal of Endocrinology 138 328-336.

Féral C, Reznik Y, Le Gall S, Mahoudeau J, Corvol P \& Leymarie P 1990 Stimulation by hCG of ovarian inactive renin synthesis in rabbit preovulatory theca cells. Journal of Reproduction and Fertility $\mathbf{8 9}$ 407-414.

Féral C, Le Gall S \& Leymarie P 1995 Angiotensin II modulates steroidogenesis in granulosa and theca in the rabbit ovary: its possible involvement in atresia. European Journal of Endocrinology 133 747-753.

Fong YY, Schermerhorn AM \& Gorospe WC 1994 Production of interleukin- 6 by rat ovarian granulosa cells following the removal of resident macrophages in vitro. Endocrine Journal 2 261-264.

Gorospe WC \& Spangelo BL 1993 Interleukin-6 production by rat granulosa cells in vitro: effects of cytokines, follicle-stimulating hormone, and cyclic 3',5'-adenosine monophosphate. Biology of Reproduction 48 538-543.

Gorospe WC, Hughes FM \& Spangelo BL 1992 Interleukin-6: effects on production by rat granulosa cells in vitro. Endocrinology $\mathbf{1 3 0}$ $1750-1752$

Gottschall PE, Katsuura G, Dahl RR, Talbot-Hoffmann S \& Arimura A 1988 Discordance in the effects of interleukin-1 on rat differentiation induced by follicle-stimulating hormone or activators of adenylate cyclase. Biology of Reproduction 39 1074-1085.

Hughes FM, Fong YY \& Gorospe WC 1994 Interleukin-6 stimulates apoptosis in FSH-stimulated rat granulosa cells in vitro: development of an in vitro model. Endocrine 2 997-1002.

Kishimoto T 1989 The biology of interleukin-6. Blood 74 1-10.

Labarca C \& Paigen K 1980 A simple, rapid, and sensitive DNA assay procedure. Analytical Biochemistry 102 344-352.

Machelon V, Emilie D, Lefevre A, Nomé F, Durand-Gasselin I \& Testart J 1994a Interleukin-6 biosynthesis in human preovulatory follicles: some of its potential roles at ovulation. Journal of Clinical Endocrinology and Metabolism 79 633-642.

Machelon V, Nome F \& Salesse R 1994b Comparative effects on FSH- and hCG-induced functions in porcine granulosa cell cultures. Cellular and Molecular Biology 40 373-380.

Machelon V, Gougeon A, Duquenne C, Testart J, Wallon C, Delattre RM, Emilie D \& Galanaud P 1995 Ovarian production of IL-6 and its potential inhibitory effect on progesterone secretion in Cynomolgus fascicularis. Comptes Rendus de l'Académie des Sciences Paris $\mathbf{3 1 8}$ $1111-1118$

Mangan DF \& Wahl SM 1991 Differential regulation of human monocyte programmed cell death (apoptosis) by chemotactic factors and pro-inflammatory cytokines. Journal of Immunology 147 $3408-3412$

Mosmann T 1983 Rapid colorimetric assay for cellular growth and survival: application to proliferation and cytotoxic assays. Journal of Immunological Methods 65 55-63.

Pitzel L, Jarry H \& Wuttke W 1993 Effects and interactions of prostaglandin F2a, oxytoxin, and cytokines on steroidogenesis of porcine luteal cells. Endocrinology 132 751-756.

Pottratz ST, Bellipo T, Mocharia H, Crabb D \& Monolages JC 1994 $17 \beta$-Estradiol inhibits expression of human IL-6 promoter-reporter constructs by a receptor-dependent mechanism. Journal of Clinical Investigation 93 944-950.

Santana P, Llanes L, Hernandez I, Gonzalez-Robayna I, Tabraue C, Gonzalez-Reyes J, Quintana J, Estevez F, Ruiz de Galarreta CM \& Fanjul LF 1996 Interleukin-1 $\beta$ stimulates sphingomyelin hydrolysis in cultured granulosa cells: Evidence for a regulatory role of ceramide on progesterone and prostaglandin biosynthesis. Endocrinology 137 2480-2489. 
Spangelo BL, Isakson PC \& MacLeod RM 1990a Production of interleukin- 6 by anterior pituitary cells is stimulated by increased intracellular adenosine $3^{\prime}, 5^{\prime}$-monophosphate and vasoactive intestinal peptide. Endocrinology 127 403-409.

Spangelo BL, MacLeod RM \& Isakson PC 1990b Production of interleukin-6 by anterior pituitary cells in vitro. Endocrinology 126 582-586.

Van Snick J 1990 Interleukin-6: an overview. Annual Review of Immunology 8 253-278.
Watson JM, Seinsintaffar JL, Berek JS \& Martiney-Maza O 1990 Constitutive production of IL- 6 by ovarian cell lines and by primary ovarian tumor culture. Cancer Research $\mathbf{5 0}$ 6959-6965.

Received 3 April 1998

Revised manuscript received 13 July 1998

Accepted 13 August 1998 